\title{
力ラ一図説
}

喉頭顕微鏡下手術のコッ

\section{Technique of Laryngomicrosurgery}

\author{
福田宏之
}

発声時に声帯に何が起きているか知ること.

声帯を扱ら者は発声機構についてかなりの知識をもつ 必要がある.なかでも声帯振動に関する深い理解が求め られる.そこで我々の基礎的研究の一端を紹介して知識 を整理してみたい. 図 1 は犬の声帯に小さな鉛を刺入し て吹鳴実験をしたものである. 鉛 (L) は声帯遊離縁に, 他の $\mathrm{M}, \mathrm{N}$ は下面の筋層に刺入されている. 声帯振動 をX線ストロボスュープにて前額面から記録し，フィル ムモーションアナライザーを用いてその軌跡を分析した ものが図 2 である。これでみると鉛 (L) のみに有意義の 運動つまり振動があるのが分かる. 他の実験の結果も加 味されての声帯振動とは何かと述べると以下のようにな る.

一一声帯振動の本質は声帯粘膜に生じた粘膜波動で声帯 下面から上面に移行してくる.すなわち粘膜の“たわみ” である。

一そしてその現象はいわゆる声帯遊離縁に顕著である. そらしてみると声帯に手術操作を加えるときには遊離 縁を大切に扱らのが理にかなっているといえる. また声 帯が “たわみやすい”ためには声帯の粘膜に適度の柔ら かさが必要であり術後に粘膜が硬くなると粘膜に“たわ み”が生じなくなる.すなわち声帯に粘膜波動がみられ なくなり嗄声のもとになり音声外科としては失敗である. そらならないための基本は以下のとおりである.

一一特に遊離縁の粘膜は可及的に保存維持する. 他の部
位の粘膜も含めて粘膜の過剩切除を避ける.

一一術後の創傷治癒が正常に行われるよらに努める.そ のためには手術操作の回数をできるだけ少なくする。で きれば 1 回の鉗子操作であっさりと切除する.

要約すると遊離縁の粘膜を大切にし, 過㮃切除を避け, 手術操作を少なくする. そのような観点から手術のコッ を述べる。

喉頭鏡の操作 : 喉頭鏡の操作は極めて大事でありこれ により正しい手術野が得られる。これで手術の成功, 不 成功は汪とんど決まってしまう。喉頭鏡操作とは深さと 角度に留意することであり，例えば図 3 に正しい深さで の声帯ポリープを示す。この状態ならば上向きか左横開 き鉗子にて 1 回の操作で一気に切除可能である.しかし 喉頭鏡を深くすると図 4 のようになり様相が一変する. もちろんこれでも 1 回操作で切除可能であるが先に比べ てやや困難である.

手術器具の選択：マイクロだからと言っていつも小さ な道具を使ら必要はない. 図 5 のよらなポリープではこ の鉗子では小さく 1 回の操作の後で残存が見込まれる. そこで図 6 のような上向きのロバートの鉗子を用いると 一挙に切除が可能であることが理解される．他にも注意 すべさことはあるが粘膜の保護, 維持と術後の創傷治癒 の完全を期待する観点から喉頭顕微鏡下手術のコツにつ いて述べた。 


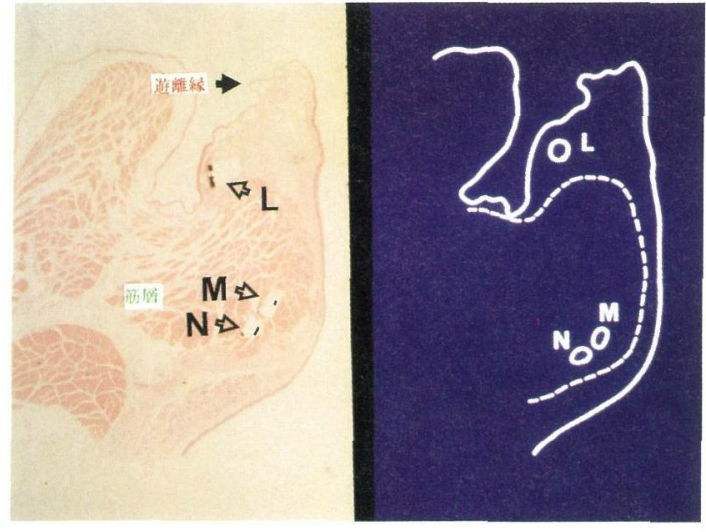

図 1 吹鳴実験. 鉛の小片の存在部位を示すための病理組織像. 啹頭筋活動時の声帯振動を前頭面から解析するため声帯 の各所に鉛の小片を刺入。

鉛 $(\mathrm{L})$ ：声帯遊縁やや外側 鉛 $(\mathrm{M})(\mathrm{N})$ ：声帯下面筋層

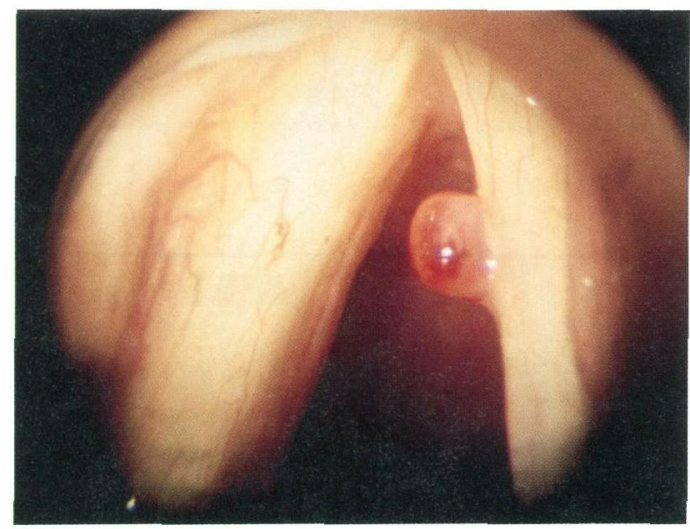

図 3 喉頭鏡が適度の深さと正確に正中に固定された場合の声 帯ポリープのイメージ。このよらな視野であれば上向き 喉鉗子で 1 回の手術操作で容易に摘出可能.

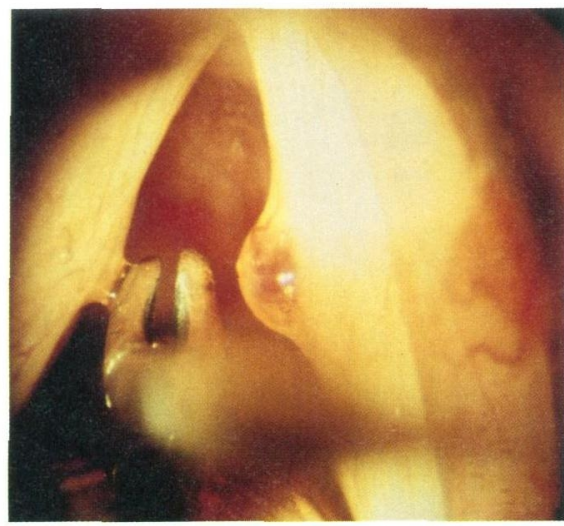

図 5 器具の選択.このようなポリープで小さな鉗子を選んだ 場合前方に残存の生じる恐れがある。

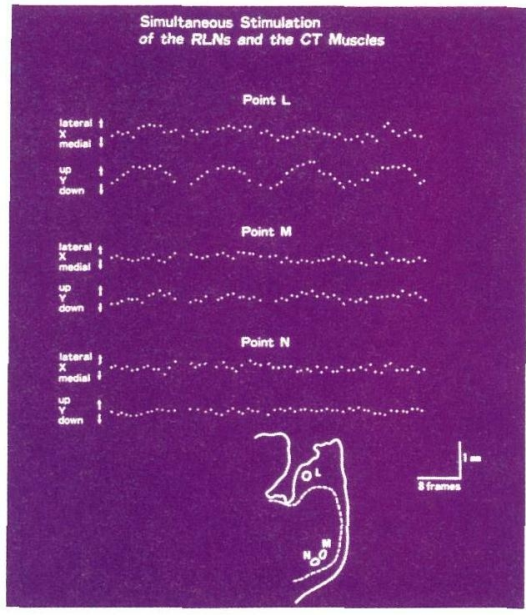

図 2 吹鳴実験. 図 1 の喉頭を吹鳴させてそれぞれの鉛の運動 解析を示す．鉛 $(\mathrm{L})$ にのみ有意義な規則性の運動が見ら れる。

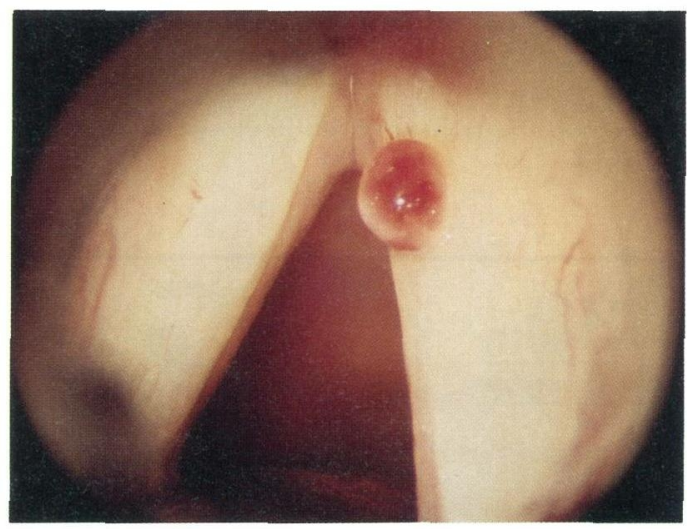

図 4 図 3 と同じ喉頭で喉頭鏡を深めに固定した場合の喉頭 像.声帯が翻転してポリープが上面に移動したよらにな り手術操作が比較してやや複雑になる.

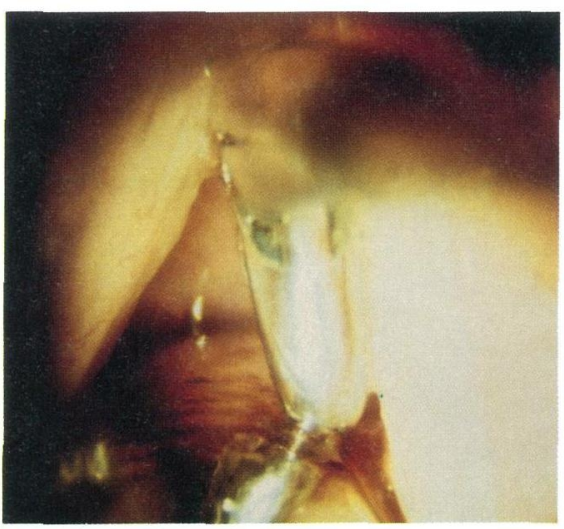

図 6 器具の選択. 図 5 のポリープではやや大きめの鉗子を選 ベばこの図に示すように一挙に銷除可能である。 